\title{
PHILOSOPHY OF LAW
}

\section{UDC: 340.12}

DOI: https://doi.org/10.26661/hst-2020-4-81-10

\section{SOCIAL PHILOSOPHICAL REFLECTION OF THE INDIVIDUAL LEGAL EDUCATION PHILOSOPHY AS THE BASIS FOR THE DEMOCRATIC SOCIETY FUNCTIONING}

\author{
CNESTERENKO, OLENA \\ Dmytro Motornyi Tavria state agrotechnological university (Melitopol, Zaporizhzhia obl., \\ Ukraine) \\ E-mail: lena.kompsa@ukr.net, \\ ORCID iD: https://orcid.org/0000-0001-5661-7083 \\ Таврійський державний агротехнологічний університет імені, пр. Хмельницького \\ 18, 72312 Мелітополь Украӥна Запорізька область \\ Dmytro Motornyi Tavria State Agrotechnological University, Hetmanskaya str., 18, 72312 \\ Melitopol, Ukraine Zaporizhzhia region
}

\section{COLEKSENKO, ROMAN}

Dmytro Motornyi Tavria state agrotechnological university (Melitopol, Zaporizhzhia obl., Ukraine)

E-mail: roman.xds1@ukr.net,

ORCID iD: https://orcid.org/ 0000-0002-2171-514X

Таврійський державний агротехнологічний університет імені, пр. Хмельницького 18, 72312 Мелітополь Украӥна Запорізька область

Dmytro Motornyi Tavria State Agrotechnological University, Hetmanskaya str., 18, 72312 Melitopol, Ukraine Zaporizhzhia region

\section{Anotation}

The actuality of the topic of scientific intelligence is due to the necessity to study the goals of legal education of society and the individual, as without these components the functioning of a democratic society and the existence of the legal state is not impossible. The goal of scientific research: social-philosophical reflection on the philosophy of law education as the basis of a democratic society, which is formed on the basis of legal norms and principles, on the legal and ethical culture of the individual as one of the main priorities of law education of socially active individuals in the democratization of modern society. The task of the research is: 1) to disclose the goals of law education as the basis for the formation of lawful behavior and the reflexion of the system of law education and "knowledge of law"; 2) to show the directions of the formation of the legal state and legal consciousness and to realize the reflexion of legal convictions of citizens, justice and responsibility; 3 ) to disclose the reflexion of legality, the need to follow legal prescriptions and solidarity with the law, as well as the reflexion of legal culture and law education as a condition for living in a legal society; 4) to realize the reflexion of law habits, legal skills and legal practices as personal qualities and the philosophy of the goals of law education of the individual as a basis for functioning of a democratic society. Methodology - methods of analysis and synthesis, abstraction, historical and logical, the transition from abstract to concrete, systematic and structural-functional analysis, which allowed for social philosophical

Social philosophical reflection of the individual legal education philosophy as the basis for the democratic society functioning 
understanding of the philosophy of law education as the basis of a democratic society, which is formed on the basis of legal norms and principles, on the legal and ethical culture of the individual. It was made a conclusion that the goals of law education are the formation of systems of legal knowledge, legal conviction, motives and habits of lawful, socially active behavior in accordance with the tasks of forming legal statehood in Ukraine. Of course, this list is not exhaustive and allows the possibility of some or other additions, but, in our opinion, it is correctly reflects the structure of legal consciousness, which consists of intellectual, emotional and volitional components.

Keywords: individual, law education, knowledge, justice, culture of law education, legal consciousness, goals of law education.

\section{Problem setting in general and its connection with important scientific or practical tasks.}

The actuality of the social philosophical discourse of the philosophy of law education as the basis for the functioning of a democratic society is not in doubt, because education, legal consciousness, legal culture, justice are the basic principles on which a democratic society and the legal system of the state are based. The importance of justice satisfies the claim of individuals to protection from aggression, violence or robbery and requires punishment for an offence, while the principles of justice regulate first of all the distribution of benefits and duties, advantages and losses in society. At the same time, it is not only a matter of moral precepts, but also of clear legal possibilities to apply legal means and, if it is necessary, require their implementation.

\section{Analysis of the recent} studies and publications from which the solution of this problem is based and on which the author relies.

The national and foreign scientific literature pays a lot of attention to the issue of law education as the basis for the functioning of a democratic society and the law educational process in educational institutions, but in our authors' opinion this issue has not been investigated to the full extent. In particular, the following scientific researchers have devoted their research to an analysis of the nature of this issue, the subjects and objects, forms and methods of implementation: From Bolonin, Voronkova, V. Golovchenko, N. Grenade, A. Nesterenko, R. Oleksenko, V. Tumanov, V. Goiman, P. Rabinovich L. Mamut, V. Chefranov and others.

The purpose of scientific research: social philosophical understanding of the philosophy of law education as the basis of a democratic society, which is formed on the basis of legal norms and principles, the legal and ethical culture of the individual as the main priorities of legal education of socially active individuals in the democratization of modern society.

To achieve the goal, the following tasks were given: - to define the categories: "education", "goals of the law education", " legal consciousness";

- to study the goals of the law education of the individual;

- to analyze the ability to implement moral self-control. 
Presentation of the main research material with the grounds for the obtained scientific results

1.The objectives of law education as the basis for the formation of lawful behavior.

An important place in the study of law education is given to the consideration of the goals of law education, because the individual is so unique that the individual metabolizes society, the world, himself and other subjects, reproducing his immanent index world in the projections and in the constitutions of activity. In general, the goal is understood as "the object of desire, what should be done, it is preferable to realize" in ontology, existence, society [1]. Education is a conscious process that supposes the presence of an active subject with the consciousness of the object being influenced, and the identification of a complex set of circumstances in which the relations between an individual and the state, an individual and society, an individual and the legal relations are formed, as well as the overcoming of contradictions which are arising as a result of the wrong use of freedom, creations, existences, objectively supposes the presence of certain goals.

The legal literature presents different views on the aims of law education. Some authors consider that law education is designed to disseminate legal knowledge, forming legal convictions, training a respect for the norms of law and the belief in the need for their implementation. Others believe that the goals of law education are also to develop the skills of lawful behavior, develop a habit of observing and complying with laws.Third, they expressed the opinion that the aim of the authoresultation of law education should be the influence of legal institutions and other social groups and individuals, which turns political and legal ideas and demands of the right into personal views of citizens [2]. We think that first of all we should agree with the opinion that the legal culture is first and foremost the goal of education.

Recently, more and more attention has been paid to the goal of legal education, such as the formation of a socially active personality, which reflects the index-denative unity or correlation of the personality with other individuals on the basis of social-ontological and creative experience of previous generations. At the same time, autonomy-rightfreedom must be ensured by political, legal and economic aspects of the state matrix. The subject should be autonomous in his covenants-actions, but he is obliged to keep the norms of ethics and jurisprudence and not to break the norms, freedom and rights of other citizens, i.e. to live in the legal field, which brings his creative and dynamic life to the socium-state [3].

At the same time, it should be noted that there is a diversity of objectives of law education united by the tasks of forming legal consciousness and training legal culture. Being a factor in the formation of legal consciousness of an

Social philosophical reflection of the individual legal education philosophy as the basis for the democratic society functioning 
individual, law education, however, does not cover the whole process of formation of legal consciousness. From the other side, even developed legal consciousness is not an absolute determinant of lawful and socially active behavior. On the basis of this thesis, M.Galimov and O.Muramets make, in our opinion, the wrong conclusion, as they exclude the achievement of lawful behavior from the goals of education. As an argument, they point out that "... high level of legal consciousness in some cases does not ensure lawful behavior ... In this case, it is well known that lawful behavior does not always indicate a high level of human legal consciousness" [4].

We are of course in agreement with these scientists that causation of behaviour is a very complex social and legal mechanism. The specific actions of people are determined by a whole range of internal and external factors, one of which is focused legal and educational activities. However, with the correct thesis that lawful behaviour is achieved as a result of the interaction of a number of internal and external factors, it cannot be concluded that legal and educational activities are not aimed at ensuring lawful behaviour [5].

Discrepancies can also be found between the developed legal consciousness and illegal behavior or, on the contrary, between legitimate behavior and a not high level of legal consciousness do not exclude the question that achieving a high level of legal consciousness is aimed at forming legitimate behavior. Law education is certainly not an absolute determinant of lawful behavior, but it is the main, decisive and determining factor in its formation. In Kudryavtsev's opinion, "the law is not able to manage and regulate a person's thoughts and should not be striving to do this; legal prescriptions acting through the mind and will, but not regulating these mental processes by themselves, but their results objectively performed actions" [6].

Law is a multifaceted phenomenon. As the well-known legal scholar S.Alekseev marks, it acts before people in three forms: compulsory norms, laws, activity of judicial and other legal institutions legal realities which the person faces in a life; special, difficult social education - a kind of subsystem in a society, has the nature and logic, the same subsystem as the state, art, morals; the phenomena of a world outlook order - one of the beginnings and displays of life of the intelligent beings, people [7]. At the same time, it is agreed that each of these "images" expresses a specific "angle of view" of understanding the right, a certain stage in comprehending its features.

\section{Reflexion of law education system and «knowledge of law »}

It seems reasonable to build a system of law education taking into consideration all these "borders". At the same time, it is necessary to take into account that legal requirements do not always influence human consciousness and behavior by the very fact of their existence. The task of law is to ensure a certain behavior of people, and its educational role is 
implemented by regulating relations. Outside of legal relations and without process, implements educational activities, the law can not implement its educational function and thus have an impact on people's consciousness and behavior [8].

One of the most important goals of law education is to form a system of legal knowledge. The task of philosophy is to watch the development of the spirit. It has three degrees: consciousness, selfconsciousness and mind. Before consciousness, as a feeling, perception and mind, there are things " by themselves". When consciousness reflexes in relation to things, it knows what they are to it. Mind recognizes itself as self-consciousness "for itself". However, this happens when it is recognized by some other selfconsciousness. Because of the need for recognition by another consciousness, subjectivity is removed, which leads to the unity of subject and object in the mind as consciousness «on its own and for itself» as knowledge [9].

Consciousness, which Hegel defined as the sensitive confidence of feelings and perceptions, is the contemplative knowledge of being, which is direct knowledge. It only knows what it is. The person who sees the object is immersed in the contemplation of the object. However, this passive contemplation carries a fundamental shock A person's desire turns the object of contemplation into an object and the object of contemplation changes the action. Human self must be the desire itself, i.e. the active self, which transforms being and creates a new being. Selfconsciousness is called upon to satisfy one's own desires, but it is called upon to go beyond its own limits in order to transform itself into the mind. Consciousness must acquire the character of reasoning, if it wants to participate in the real historical process, must find a single and systematic order for the mind to become reality [10].

By «knowing the law» is meant the knowledge of the objects of education in matters of law, a set of acquired legal concepts and terms, become a reality. However, the category "knowledge of law" is not reduced to mere awareness of the existence of some legal norms with this or that content. It covers comprehension of the law, understanding of its essence, awareness of its meaning for subjects of social relations [11].

Without sufficient knowledge of the law, a person could not comprehensively justify and form a positive attitude to the law. Knowledge of the law makes it possible to consciously organize one's behavior, to control it from the legal point of view. The indicators of knowledge of law serve as motivation for each citizen for the expediency of existence of data, not other legal norms [12]. Philosophy is seen as an absolute judge who evaluates individuals; it turns into realism.

\section{Formation of the legal state and conscience of law.}

It should also be taken into

Social philosophical reflection of the individual legal education philosophy as the basis for the democratic society functioning 
consideration that the formation of the legal state in a society with low legal awareness of citizens is impossible. That is why modern philosophy, aiming at the formation of a state based on the rule of law, has constitutionally enshrined the following provisions: laws are subject to official publication; unpublished laws are not applied; any normative legal acts relating to the rights, freedoms and obligations of a person and a citizen may not be applied if they are not officially made public [13].

Of course, such an interpretation of this category should not be understood as requiring mandatory possession of all legal knowledge. However, ignorance of the law does not exempt a person from responsibility, and a person often finds himself or herself in such life situations when he or she has to make decisions without, for example, having the opportunity to obtain the necessary legal advice, and modern moral criteria are not always able to ensure that decisions that meet the requirements of the law are taken [14].

The second, more serious and complex aspect (goal) of the process of formation of legal consciousness is considered to be education of respect for the law, which implies not only knowledge and assimilation of legal ideas, principles and norms to a certain extent, but also personal positive attitude towards them. One can be well acquainted with these ideas and principles, but not to share them, not to consider them right, fair and in line with the interests of the person. It happens that offenders, especially recidivists, are well aware of the existing legislation (of course, they know only the criminal legislation, and the fact that, as a rule, a certain group of norms corresponds most to them, so to speak, "Profile"), which does not prevent them, in itself, from committing new crimes. At the same time, it should be borne in mind that the condition for a number of offences, especially those committed by adolescents, is precisely ignorance of the law, in particular the borderline separating trickery, mischief from mischief or even crime [15].

After all, respect for the law is not only an attitude to the law in a narrow, special sense (as in a normative act of the supreme authority) and, or in its broad sense (as in any normative act). It means respect for all state and legal phenomena: all kinds of legal acts, state bodies, officials and their activities on creation, application, implementation, protection of legal norms, law and order, subjective rights and duties of all other participants of legal communication.

The daily practice of law education of the population often focuses on enabling people to acquire a certain amount of legal knowledge. This is certainly important, but it should be borne in mind that knowledge of certain norms or principles does not yet mean that it becomes an integral part of a person's beliefs. Knowledge, as Yu. Ageshin correctly notes, must be distinguished from beliefs [16].

4.Reflection on the legal persuasion of citizens, justice and 


\section{responsibility}

The legal beliefs of citizens are based on their deep awareness of the social value of legal norms. Beliefs touch the senses, evoke feelings that contribute to a stronger fixation in the consciousness of the basic ideas, principles, specific prescriptions established in legal norms. Such awareness allows for a better understanding of the content of the law's requirements, for a more objective assessment of the behaviour of specific subjects, for choosing from many other optimal and lawful options of one's own behaviour. Based on personal legal convictions, a person develops the ability to exercise moral self-control. In other words, internal legal convictions act as a component of individual legal consciousness, on the basis of which respect for the law, the law is formed and the social, ideological and political value of the law and its basic principles is better understood. At the same time, the "breeding ground" of the convictions themselves is the legal and life experience of citizens, social and legal practice and, to a large extent, legal knowledge [17].

The educational impact is that the subject of social education takes an interest in the legal norms and institution while remaining indifferent. Thus, to bring up legal feelings means to form them in such a way that subjects of social relations respond to legal events, expressing their attitude to them, giving them appropriate assessment.

Emotional goals of legal education can be considered the formation of feelings of justice, responsibility and legality and do nothing against their conscience. All these goals are interconnected and interdependent. Indeed, it is hardly possible to develop a sense of legality if a person has not developed a sense of justice [18].

Reflexion of citizens' legal beliefs leads to the formation of a sense of justice; it means not only the ability to evaluate the correctness of, for example, a legislative act, but above all the ability to produce criteria for legal evaluations. A sense of justice means the extent to which an individual feels that he or she has a right, expressed in his or her respect for the rights and legitimate interests of others, in responsibility and behaviour, and in the demand for fair conduct addressed to others [19].

A sense of responsibility is a person's conscious attitude towards his or her rights and responsibilities, understanding and assessment of his or her actions and their legal consequences. It provides for the unconditional performance of duties by all subjects of legal relations. Unfortunately, there are still many cases that testify to the weak development of this legal feeling.

5. Reflection on legality, the need to follow legal prescriptions and solidarity with the law

One important goal of legal education is to cultivate a sense of legality, i.e. to form a consciousness among members of society that all decisions should be made on the basis of the law, more specifically, the choice of the option of lawful 
behavior, readiness to follow legal instructions in this direction. The feeling of legality is the inner mood of a person to choose only legal-like behavior, even if it does not suit the addressee in some sense, does not correspond to his interests at the moment (say, in case of imperfect prescription). It is possible to internally disagree with what provision of the law, but at the same time to execute it, considering that as long as the law is in force, it should be observed. A negative attitude to the observance of the law is not always the consequence of the same awareness of the law itself [20]. A person with a developed sense of law invariably protests against any deviation from legal norms and condemns it. This feeling is always aimed at restoring the rule of law in case of its violation, at bringing offenders to justice.

According to Gooman, the exercise of legal activity is largely determined by the direction of legal activity, which is in turn driven by value-based personality traits, such as a sense of solidarity with the law and a sense of legal duty [21]. Solidarity with the law is an attitude towards legal norms based on agreement with them, their demands and the need to follow legal prescriptions. The degree of an individual's consent to a norm may vary, depending on the motives underlying such consent. For example, where the same legal rule is dissatisfied, the legal requirements of different individuals may vary.

The sense of legal (civil, publiclegal, professional) duty indicates the nature of a person's understanding of the meaning of legal means, the degree of readiness for use in practical activities to satisfy primarily public interests or the interests of other persons. A sense of legal duty mobilizes an individual to actively fight for the law if it is sufficiently developed, and "dulls" the taste for legal work if it is not sufficiently expressed in the personal structure [22].

\section{Reflexion of legal culture and law education as a condition for living in a legal society}

All of the above senses are united in one basic value-legal orientation that characterizes the high level of legal culture - respect for the law. This means recognition of the social value of the law, including sufficient awareness of the requirements of the law and solidarity with the principles of the law. It is characterised not only by a desire to comply with the prescriptions and to align one's behaviour with the models proposed by the law, but also by social action to contribute to the strengthening of law and order. A broader definition of this concept is given by P. Rabinovich, according to which "respect for the law is a firm belief in its high value for all members of society, expressed in the attitude of the subject to unconditional lawful conduct" [23].

There is no doubt that the process of forming respect for the law does not happen automatically. On the one hand, an effective system of influencing people's will and consciousness, emotions and perceptions is needed to ensure a 
positive attitude towards the right, its correct assessment and adequate behaviour of the individual himself. On the other hand, this process cannot be effective if you count on the power of external influence. Respect for the right is possible only on the basis of a person's deep personal belief in the value of the political and social and legal principles proclaimed by society. Thus, any external educational impact must have at its core the creation of the most favourable conditions for the development of personal initiative. And only under this condition will it be possible to make a qualitative leap in respect of legal values and norms, which, in turn, will affect the behavior of each person [24].

In the system of law education goals, behavioural goals aimed at encouraging citizens to be active in lawmaking, administration, justice and control functions are of particular importance. In particular, legal education implies that citizens are interested in having quality, effective legislation and in implementing certain actions on this basis. For example, the indicators of legal education in this area may be statements of proposals for the adoption of a certain normative act, participation in the discussion of its project, participation in the implementation of the adopted normative document. A citizen, properly brought up in the legal sense, cannot but participate in the discussion and solution of public administration issues, not to express his opinion on them. Besides, a citizen should consider court as an important social institution, be able to apply to court for protection of his subjective rights and legal interests. Legal education also presupposes citizen's participation in the control over the state bodies, appealing to them with the requirement to fulfill the duties imposed on them, taking measures to bring to responsibility the persons violating the laws and the like [25].

If we proceed from the assumption that the phenomenon of stereotyping is the basis for the formation of the properties of the behavioural block, the essence of which is that in the process of external influences repeatedly repeated in the same conditions, certain stereotyped forms of legal behavior ("templates") are formed and fixed in the structure of the personality, then a number of behavioural properties in the field of law can be presented as follows: legal skills, legal skills, legal habits, customary legal preparedness.

\section{Reflexion of legal abilities, legal skills and legal habits as personal qualities}

Reflexion of legal skills and legal skills as personal qualities are legal properties, meaning that standardized methods of realization of rights, duties and other components of legal reality are fixed in the consciousness of the subject. They are characterized by a high degree of development of various processes of legal reality on the basis of the knowledge received earlier, as a result of which manifestation of legal activity does not cause great personal efforts. Legal skills intensify the

Social philosophical reflection of the individual legal education philosophy as the basis for the democratic society functioning 
process of legal activity transfer from the state of "rest" to the state of lawful behavior, bringing it to a high degree of automatism [26].

Legal skills represent the personal qualities characterizing the ability of a person to make a purposeful impact on certain phenomena, processes of legal reality in order to cause the necessary changes in them. Legal skills are directly dependent on the development of a person's informative legal properties, and at the same time they are dependent on value-oriented properties that stimulate their development [27].

Legal habits are considered to be patterns of personal behaviour, established as a result of multiple repetition due to personal needs or external coercion in certain situations mediated by law. Legal habits are the same legal skills, but are considered on a slightly different plane, characterizing the process of legal activity from its motivational side. A legal habit is a person's own internal need to manifest legal activity of a certain intensity. In other words, as legal skills are the ability to perform external actions that are required by legal communication (choice of an appropriate counterpart, conclusion of an agreement, exchange of benefits, obtaining appropriate, compensation for damages, etc.) as approved stereotypical techniques. It should be noted here that the formation and manifestation of legal habits is possible not only due to personal needs, but also due to the influence of external forces on the personality [28].

In a number of works with the correct overall approach to the disclosure of the content of legal education underestimates such an important aspect of it as the formation of practical skills and ability to apply legal provisions in practice. Meanwhile, as V.Chefranov correctly noted, if the legal knowledge acquired by an individual does not pass into the values, does not become internal convictions, does not receive emotional coloring, is not fixed in the legal habits and skills of the normative-evaluation character, in the skills, it may indicate the frailty of legal consciousness in general. In other words, no matter how deeply the law is studied, no matter how high the level of legal knowledge is, legal prescriptions will not be implemented automatically without corresponding convictions, without people's practical activity [29]. This moment is of particular importance in contemporary conditions, since the acceleration of the pace of life increasingly creates for people new and sometimes unexpected situations in which minimum time is allocated for decision-making and the decisionmaking mechanism cannot be reduced to imitation or instant instruction. In such cases, sustainable, preformed individual psychological qualities as a result of legal education are becoming increasingly important. Here, the main role is played by what constitutes the individual, the individual's personal role and responsibility for decisionmaking are increasing.

8. Socio-philosophical discourse of philosophy of the goals of law education of the individual as a 


\section{basis for functioning of a democratic society}

When investigating the goals of legal education, the question arises as to their correlation. In the legal literature there is an approach according to which the studied goals should be divided into the nearest goal - the formation of systems of legal knowledge, the intermediate goal - the formation of legal certainty, and the final goal - the formation of motives and habits of lawful behavior [30]. In our opinion, such a division is not sufficiently justified, as it is not convincingly proved that one of these goals is the main, the nearest one, and the other one is perspective or secondary. It would be wrong to think that first efforts are made to achieve one, then another, and finally a third goal. It should be stressed that all the goals of legal education are interconnected and form a single, coherent system. That is why we can talk about the simultaneous achievement of all the goals, but taking into account their multistage nature and the peculiarities of each of them.

Of course, in practical legal education activities with different categories of population, not all goals can be achieved simultaneously. Moreover, at one stage or another, it is useful to identify the most important goal for each specific group. In some cases, it may be to increase legal knowledge, instil a sense of respect for the law and a conviction that it is necessary to comply with it; in others, it may be to instil skills for lawful conduct; in others, it may be to instil social and legal activity. More specific goals may also be defined.

To a large extent, legal education is directly oriented towards combating offences and preventing crimes and misdemeanours. This social purpose of legal education cannot be underestimated. Its orientation towards eliminating defects in the legal consciousness of persons prone to offences is quite justified. The tasks of strengthening the rule of law require it. However, this does not limit the role of legal education. Much more often legal education measures are oriented at law-abiding persons whose legal consciousness cannot be considered defective. Therefore, in the legal literature and law enforcement practice, considerable attention is paid to the prevention of offences. Increasing the effectiveness of crime prevention is a task of utmost importance, and legal education of the population is also aimed at solving it.

Some authors believe that in the most general form legal education should lead to the following three conditionally identified basic requirements. First, a legal consciousness must be cultivated in order to prevent the commission of offences in a favourable situation. Secondly, the more complex task of legal education is to ensure the level of legal consciousness, to exclude illegal conduct in a typical unfavorable situation. Third, an important task is seen as educating citizens in such a way that they refrain from committing offences not only in a favourable and typically 
unfavourable situation in the criminal sense. At the same time, legal education acts as a condition of ensuring, first of all, the regulating rather than protective function of law. Legal education in such cases affects the numerous aspects of legal consciousness reflecting legal phenomena not directly related to the application of punitive, coercive measures [30].

\section{Conclusions of the research work}

At the same time, we will conclude that law education is not limited to the prevention of offences. After all, law is a regulator of various social relations, not just a means of the struggle against violations. Legal regulation and legal protection are two independent, though interrelated processes that are crossing over in a certain part of their content. We think that the goals of legal education are the formation of systems of legal knowledge, legal certainty, motives and habits of lawful, socially active behavior in accordance with the tasks of forming legal statehood in Ukraine. Of course, this list is not exhaustive and suggests the possibility of certain additions, but, in our opinion, it properly reflects the structure of legal consciousness, which, as we know, consists of intellectual, emotional and volitional components.

\section{СПИСОК ВИКОРИСТАНИХ ДЖЕРЕЛ}

1. Андрюкайтене Р. Олексенко Р., 2018. До формування світоглядних орієнтирів сучасної людини Всеукраїнська науковопрактична конференція 3 міжнародною участю до 95-річчя Мелітопольського державного педагогічного університету імені Богдана Хмельницького "Дискурс в умовах мінливості соиіокультурного простору". 8-10.

2. Андрусишин Р. М., 2016. Правове виховання працівників ОВС : теоретикоправовий вимір : дис. ... канд. юрид. наук : 12.00.01. Львів. 226.

3. Buhaichuk Oksana, 2019. Strategies of information and innovation activity development at enterprise in digital conditions. HUMANITIES STUDIES: Collection of Scientific Papers. Zaporizhzhia: ZNU. 1 (78). 75-85.

4. Voronkova Valentyna, Metelenko Natalya, Nikitenko Vitalina, Silina Iryna, 2019. System analysis of the economy of sustainable development as environmentally balnced and socially oriented one. HUMANITIES STUDIES: Collection of Scientific Papers. Zaporizhzhia: ZNU. 1 (78). 86-97.

5. Воронкова В. Г., 2008. Філософія гуманістичного менеджменту (соціальноантропологічні виміри): монографія. Запоріжжя: РВВ ЗДІА. 254.

6. Voronkova V., Kyvliuk O., 2017.Philosophical Reflection Smart-Society as a New Model of the Information Society and its Impact on the Education of the 21st Century. Future Human Image. 7. 154-162.

7. Жинкин С. А., Головченко Г. А., 2016. Значение правового воспитания в закреплении социально-правовых ценностей в правосознании личности. Теория $u$ практика общественного развития. 1. 49-51.

8. Zhuravel Kristina, 2019. Concept of flexible management at enterprise in digitalization and lean production conditions. HUMANITIES STUDIES: Collection of Scientific Papers. Zaporizhzhia: ZNU. 1 (78). 98-107.

9. Капітаненко Н. П., 2010. Азартні ігри за законодавством України, Росії та Білорусі: порівняльно-правовий аспект. Держава та регіони. Сер. Право. 1. 144-149. 
10. Кириченко Микола, 2019. Вплив цифрових технологій на розвиток людського і соціального капіталу в умовах діджиталізованого суспільства. HUMANITIES STUDIES: Collection of Scientific Papers. Zaporizhzhia: ZNU. 1 (78). 108-129.

11. Melnik Victoria, 2019. Agile-management 3.0 concept as a factor of technological progress development in the digital society. HUMANITIES STUDIES: Collection of Scientific Papers. Zaporizhzhia: ZNU. 1 (78). 130-139.

12.Недюха М., 2012. Правова ідеологія: основні теоретико-методологічні підходи до визначення поняття. Публічне право. 3. 299-306.

13. Nikitenko V.O., 2013. Problem field of the geokul' turnogo phenomenon: scientific approaches Gileâ (Research Bulletin): Col. Sciences. Ave: publishing SCIENCE LLC NVP.71. 500-504

14. Nikitenko, Vitalina, 2020. Culture and civilization: interaction and relationship in the context of social and philosophical analysis. Humanities Studies. 3 (80). 49-64.

15. Нікітенко В. О., 2013. Геокультурні цінності в умовах сучасного світового розвитку: соціально-філософський вимір. Гуманітарний вісник Запорізької державноі інженерної академї. 54. 266-280.

16. Nikitenko V. O., 2013. Problem field of the geokul' turnogo phenomenon: scientific approaches. Gileâ (Research Bulletin): Col. Sciences. Ave: publishing SCIENCE LLC NVP. $71.500-504$

17. Теорія держави і права України: підручник, 2018 / О. М. Бандурка та ін. Харків: Майдан. 452.

18. Філософія правового виховання, 2012 / А. П. Гетьман та ін.; за ред. А. П. Гетьман, О. Г. Данильяна. Харків: Право. 248.

19. Нестеренко О. М., 2015. Актуальні проблеми та цілі правового виховання молоді. Науковий вісник Ужгородського наиіонального університету. Серія: Право. 35, ч. 2, Т. 1. 53-55.

20.Нестеренко О. М., 2016. Аналіз підходів до розуміння поняття правового виховання в сучасній юридичній науці. Науковий вісник Херсонського держсвного університету. Серія: Юридичні науки. 2, Т. 1. 19-21.

21.Нестеренко О. М., 2020. Сучасне правове виховання в Свропі як один із способів формування свідомого громадянина. In: Публічне управління та адміністрування у цифровому суспільстві: монографія. Ф. О.-П. Однорог, Мелітополь, 30-38.

22. Нестеренко О.М., 2019. Правове виховання у сучасному суспільстві: теоретикокомпаративістське дослідження: дис...канд. юр. наук: 12.00.01. Харків. 260.

23. Олексенко Р., 2013. Економічна освіта і виховання як засоби розвитку світоглядних засад сучасного підприємництва. Вищза освіта Украйни. 4. 80-83.

24. Олексенко Р. І., 2013. Глобальні проблеми філософії від Античності до сьогодення в дискурсі ринкових трансформацій. Придніпровські соціально-гуманітарні читання: у 6-ти частинах. Ч. 2: матеріали Дніпропетровської сесї II Всеукр. наук.практ. конф. з міжнародною участю. 148-151.

25. Олексенко Р. І., 2014. Правове і соціально-економічне підгрунтя ринкової економіки. Гілея: науковий вісник. 80. 266-270.

26. Олексенко Р., Афанасьєва Л., 2019. Экономико - правовой механизм реализации новой модели современной культурной политики Украины. Международная научнопрактическая заочная конференция «Актуальныле проблемы экономики, менеджмента и маркетинга в современных условиях» 23 января 2019 г. 421-425.

27. Соснін О. В., Воронкова В. Г., Ажажа М. А., 2016. Філософія гуманістичного менеджменту (соціально-політичні, соціально-економічні, соціально-антропологічні виміри): навчальний посібник. Запоріжжя: Дике поле. 356.

Social philosophical reflection of the individual legal education philosophy as the basis for the democratic society functioning 
28. Тацій, В. Я., Гетьман, А. П., Данильян, О. Г., Герасіна, Л. М., Дзьобань, О. П., Калиновський, Ю. Ю., Мануйлов, С. М., 2013. Правове виховання в сучасній Україні. 2-ге вид., переробл. і допов. Х. : Право. 440. ISBN 978-966-458-526-9

29. Управління людськими ресурсами: філософські засади, 2006: навч. посібник / В. Г.Воронкова, А. Г.Беліченко, О. М.Попов та ін.К.: Професіонал.576.

30.Утюж І.Г., 2009. Цивілізаційна парадигма освіти: теоретико-методологічний аспект. Гуманітарний вісник Запорізької державної інженерної академії. 38 60-66.

\section{REFERENCES}

1. Andryukajtene, R. \& Oleksenko, R., 2018. Do formuvannya svitoglyadny`x oriyenty`riv suchasnoyi lyudy`ny` Vseukrayins`ka naukovoprakty`chna konferenciya z mizhnarodnoyu uchastyu do 95-richchya Melitopol's`kogo derzhavnogo pedagogichnogo universy`tetu imeni Bogdana Xmel`ny`cz`kogo "Dy`skurs $v$ umovax minly`vosti sociokul turnogo prostoru". 8-10.

2. Andrusy`shy`n, R. M., 2016. Pravove vy`xovannya pracivny`kiv OVS : teorety`ko-pravovy`j vy`mir : dy`s. ... kand. yury`d. nauk : 12.00.01. L`viv. 226.

3. Buhaichuk, Oksana, 2019. Strategies of information and innovation activity development at enterprise in digital conditions. HUMANITIES STUDIES: Collection of Scientific Papers. Zaporizhzhia: ZNU. 1 (78). 75-85.

4. Voronkova, Valentyna, Metelenko, Natalya, Nikitenko, Vitalina \& Silina, Iryna, 2019. System analysis of the economy of sustainable development as environmentally balnced and socially oriented one. HUMANITIES STUDIES: Collection of Scientific Papers. Zaporizhzhia: ZNU. 1 (78). 86-97.

5. Voronkova, V. H., 2008. Filosofiia humanistychnoho menedzhmentu (sotsialnoantropolohichni vymiry): monohrafiia. Zaporizhzhia: RVV ZDIA. 254.

6. Voronkova, V. \& Kyvliuk, O., 2017. Philosophical Reflection Smart-Society as a New Model of the Information Society and its Impact on the Education of the 21st Century. Future Human Image. 7. 154-162.

7. Zhinkin, S. A. \& Golovchenko, G. A., 2016. Znachenie pravovogo vospitaniia v zakreplenii sotsialno-pravovykh tsennostei $\mathrm{v}$ pravosoznanii lichnosti. Teoriia $i$ praktika obshchestvennogo razvitiia. 1. 49-51.

8. Zhuravel, Kristina, 2019. Concept of flexible management at enterprise in digitalization and lean production conditions. HUMANITIES STUDIES: Collection of Scientific Papers. Zaporizhzhia: ZNU. 1 (78). 98-107.

9. Kapitanenko N. P., 2010. Azartni ihry za zakonodavstvom Ukrainy, Rosii ta Bilorusi: porivnialno-pravovyi aspekt. Derzhava ta rehiony. Ser. Pravo. 1. 144-149.

10. Kyrychenko, Mykola, 2019. Vplyv tsyfrovykh tekhnolohii na rozvytok liudskoho i sotsialnoho kapitalu v umovakh didzhytalizovanoho suspilstva. HUMANITIES STUDIES: Collection of Scientific Papers. Zaporizhzhia: ZNU. 1 (78). 108-129.

11. Melnik, Victoria, 2019. Agile-management 3.0 concept as a factor of technological progress development in the digital society. HUMANITIES STUDIES: Collection of Scientific Papers. Zaporizhzhia: ZNU.1 (78). 130-139.

12. Nedyuxa, M., 2012. Pravova ideologiya: osnovni teorety`ko-metodologichni pidxody` do vy`znachennya ponyattya. Publichne pravo. 3. 299-306.

13. Nikitenko, V. O., 2013. Problem field of the geokul' turnogo phenomenon: scientific approaches. Gileâ (Research Bulletin): Col. Sciences. Ave: publishing SCIENCE LLC NVP. 71. 500-504

14. Nikitenko, Vitalina, 2020. Culture and civilization: interaction and relationship in the context of social and philosophical analysis. Humanities Studies. 3 (80).49-64.

15. Nikitenko V. O., 2013. Heokulturni tsinnosti v umovakh suchasnoho svitovoho rozvytku: sotsialno-filosofskyi vymir. Humanitarnyi visnyk Zaporizkoi derzhavnoi inzhenernoi akademii. 54. 266-280. 
16. Nikitenko V. O., 2013. Problem field of the geokul' turnogo phenomenon: scientific approaches. Gileâ (Research Bulletin): Col. Sciences. Ave: publishing SCIENCE LLC NVP. 71. 500-504

16. Teoriya derzhavy` i prava Ukrayiny`: pidruchny`k, 2018 / O. M. Bandurka ta in. Xarkiv: Majdan. 452.

17. Filosofiya pravovogo vy`xovannya, 2012 / A. P. Get'man ta in.; za red. A. P. Get`man, O. G. Dany`lyana. Xarkiv: Pravo. 248.

18. Nesterenko, O. M., 2015. Aktual`ni problemy` ta cili pravovogo vy`xovannya molodi. Naukovy`j visny`k Uzhgorods`kogo nacional’nogo universy`tetu. Seriya: Pravo. 35, ch. 2, T. 1.53-55.

19. Nesterenko, O. M., 2016. Analiz pidxodiv do rozuminnya ponyattya pravovogo vy`xovannya v suchasnij yury`dy`chnij nauci. Naukovy`j visny`k Xersons`kogo derzhavnogo universy`tetu. Seriya: Yury`dy`chni nauky`. 2. T. 1. 19-21.

20. Nesterenko, O. M., 2020. Suchasne pravove vy`xovannya v Yevropi yak ody`n iz sposobiv formuvannya svidomogo gromadyany`na. In: Publichne upravlinnya ta administruvannya u cy`frovomu suspil`stvi: monografiya. F. O.-P. Odnorog, Melitopol`. 3038 .

21. Nesterenko, O. M., 2019. Pravove vy`xovannya u suchasnomu suspil`stvi: teorety`kokomparaty`vists 'ke doslidzhennya: dy`s...kand. yur. nauk: 12.00.01. Xarkiv. 260.

22. Oleksenko, R., 2013. Ekonomichna osvita i vy`xovannya yak zasoby` rozvy`tku svitoglyadny`x zasad suchasnogo pidpry`yemny`cztva. Vy`shha osvita Ukrayiny`. 4. 80-83.

23. Oleksenko, R. I., 2013. Global`ni problemy` filosofiyi vid Anty`chnosti do s`ogodennya $\mathrm{v}$ dy`skursi ry`nkovy`x transformacij. Pry`dniprovs`ki social`no-gumanitarni chy`tannya: u 6-ty` chasty`nax. Ch. 2: materialy`Dnipropetrovs`koyi sesiyi II Vseukr. nauk.prakt. konf. z mizhnarodnoyu uchastyu. 148-151.

24. Oleksenko, R. I., 2014. Pravove i social`no-ekonomichne pidg`runtya ry`nkovoyi ekonomiky`. Gileya: naukovy`j visny`k. 80. 266-270.

25. Oleksenko, R., Afanaseva, L. , 2019. Ekonomiko - pravovoi mekhanizm realizatsii novoi modeli sovremennoi kulturnoi politiki Ukrainy. Mezhdunarodnaia nauchnoprakticheskaia zaochnaia konferentsiia «Aktualnye problemy ekonomiki, menedzhmenta $i$ marketinga $v$ sovremennykh usloviiakh» 23 ianvaria 2019 g. 421-425.

26. Sosnin, O. V., Voronkova, V. H. \& Azhazha, M. A., 2016. Filosofiia humanistychnoho menedzhmentu (sotsialno-politychni, sotsialno-ekonomichni, sotsialnoantropolohichni vymiry): navchalnyi posibnyk. Zaporizhzhia: Dyke pole. 356.

27. Tacij, V. Ya., Get`man, A. P., Dany`lyan, O. G., Gerasina, L. M., Dz’oban`, O. P., Kaly`novs`ky`j, Yu. Yu. \& Manujlov, Ye. M., 2013. Pravove vy`xovannya v suchasnij Ukrayini. 2-ge vy`d., pererobl. i dopov.X. : Pravo. 440. ISBN 978-966-458-526-9

28. Upravlinnia liudskymy resursamy: filosofski zasady: navch.posibnyk, 2006 / V. H. Voronkova, A. H. Belichenko, O. M. Popov ta in.K.: Profesional. 576.

29. Utiuzh, I. H., 2009. Tsyvilizatsiina paradyhma osvity: teoretykometodolohichnyi aspekt. Humanitarnyi visnyk Zaporizkoi derzhavnoi inzhenernoi akademii. 38. 60-66.

НЕСТЕРЕНКО О. М. - кандидат юридичних наук, старший викладач кафедри публічного управління, адміністрування та права, Таврійський державний агротехнологічний університет ім. Дмитра Моторного (Мелітополь, Запорізька обл., Україна)

E-mail: lena.kompsa@ukr.net

ORCID ID: https://orcid.org/0000-0001-5661-7083

Social philosophical reflection of the individual legal education philosophy as the basis for the democratic society functioning 
ОЛЕКСЕНКО, Р. І. - доктор філософських наук, професор, професор кафедри публічного управління, адміністрування та права, Таврійський державний агротехнологічний університет імені Дмитра Моторного (Мелітополь, Запороізька обл., Україна)

E-mail: roman.xds1@ukr.net,

ORCID iD: https://orcid.org/ 0000-0002-2171-514X

\section{СОЦАЛЬНО-ФІЛОСОФСЬКА РЕФЛЕКСІЯ ФІЛОСОФІЇ ПРАВОВОГО ВИХОВАННЯ ОСОБИСТОСТІ ЯК ОСНОВИ ФУНКЦІОНУВАННЯ ДЕМОКРАТИЧНОГО СУСПІЛЬСТВА}

\section{Анотація}

Актуальність теми наукової розвідки обумовлена необхідністю дослідження цілей правового виховання суспільства та особистості, так як без цих складових не можливе функціонування демократичного суспільства та існування правової держави. Мета наукової розвідки: соціально- філософське осмислення філософії правового виховання як основи демократичного суспільства, що формується на правових нормах i принципах, на правовій та етичній культурі особистості як одного 3 основних пріоритетів правового виховання соціально активної особистості в умовах демократизації сучасного суспільства. Завдання дослідження: 1) розкрити цілі правового виховання як основи формування правомірної поведінки та рефлексію системи правового виховання та «знання права»; 2) показати напрями формування правової держави та правової свідомості та здійснити рефлексію правових переконань громадян, справедливості та відповідальності; 3) розкрити рефлексію законності, необхідності слідувати правовим приписам та солідарності 3 правом, а також рефлексію правової культури і правового виховання як умови жити у правовому суспільстві; 4) здійснити рефлексію правових навичок, правових вмінь та правових звичок як особистісних якостей та філософії цілей правового виховання особистості як основи функціонування демократичного суспільства. Методологія методи аналізу і синтезу, абстрагування, історичного i логічного, переходу від абстрактного до конкретного, системного і структурно-функціонального аналізу, що дозволили здійснити соціально- філософське осмислення філософії правового виховання як основи демократичного суспільства, що формується на правових нормах і принципах, на правовій та етичній культурі особистості. Зроблено висновок, що цілями правового виховання є формування систем правових знань, правової переконаності, мотивів і звичок правомірної, соціально-активної поведінки відповідно до завдань формування правової державності в Україні. Звичайно, даний перелік не $\epsilon$ вичерпним i припускає можливість тих чи інших доповнень, але, на нашу думку, він належним чином відображає структуру правосвідомості, яка складається 3 інтелектуальних, емоційних і вольових компонентів.

Ключові слова: особистість, правове виховання, знання, справедливість, культура правового виховання, правосвідомість, цілі правового виховання.

НЕСТЕРЕНКО Е.Н. - кандидат юридических наук, старший преподаватель кафедры публичного управления, администрирования и права, Таврический государственный агротехнологический университет им. Дмитрия Моторного (Мелитополь, Запорожская обл., Украина)

E-mail: lena.kompsa@ukr.net;

ORCID ID: https://orcid.org/0000-0001-5661-7083 
ОЛЕКСЕНКО, Р. И. - доктор философских наук, профессор, профессор кафедры публичного управления, администрирования и права, Таврический государственный агротехнологический университет имени Дмитрия Моторного (Мелитополь, Запорожская обл., Украина)

E-mail: roman.xdsl@ukr.net,

ORCID iD: https://orcid.org/ 0000-0002-2171-514X

\section{СОЦИАЛЬНО-ФИЛОСОФСКАЯ РЕФЛЕКСИЯ ФИЛОСОФИИ ПРАВОВОГО ВОСПИТАНИЯ ЛИЧНОСТИ КАК ОСНОВЫ ФУНКЦИОНИРОВАНИЯ ДЕМОКРАТИЧЕСКОГО ОБЩЕСТВА}

\section{Аннотация.}

Актуальность темы научного исследования обусловлена необходимостью исследования целей правового воспитания общества и личности, так как без этих составляющих невозможно функционирование демократического общества и существования правового государства. Цель научного исследования: социальнофилософское осмысление философии правового воспитания как основы демократического общества, которое формируется на правовых нормах и принципах, на правовой и этической культуре личности как одного из основных приоритетов правового воспитания социально активной личности в условиях демократизации современного общества. Задачи исследования: 1) раскрыть цели правового воспитания как основы формирования правомерного поведения и рефлексию системы правового воспитания и «знание права»; 2) показать направления формирования правового государства и правового сознания и осуществить рефлексию правовых убеждений граждан, справедливости и ответственности; 3) раскрыть рефлексию законности, необходимости следовать правовым предписаниям и солидарности с правом, а также рефлексию правовой культуры и правового воспитания как условия жизни в правовом обществе; 4) осуществить рефлексию правовых навыков, правовых умений и правовых привычек как личностных качеств и философии целей правового воспитания личности как основы функционирования демократического общества.

Методология - методы анализа и синтеза, абстрагирования, исторического и логического, перехода от абстрактного к конкретному, системного и структурнофункционального анализа, позволили осуществить социально философское осмысление философии правового воспитания как основы демократического общества, которое, в свою очередь, формируется на правовых нормах и принципах, на правовой и этической культуре личности. Сделан вывод, что целями правового воспитания является формирование систем правовых знаний, правовой убежденности, мотивов и привычек правомерного, социально-активного поведения в соответствии с задачами формирования правовой государственности в Украине. Конечно, данный перечень не является исчерпывающим и предполагает возможность тех или иных дополнений, но, по нашему мнению, он должным образом отражает структуру правосознания, которая состоит из интеллектуальных, эмоциональных и волевых компонентов.

Ключевые слова: личность, правовое воспитание, знание, справедливость, культура правового воспитания, правосознание, цели правового воспитания

Received date 10.04.2020

Accepted date 15.04.2020

Published date 10.05.2020

Social philosophical reflection of the individual legal education philosophy as the basis for the democratic society functioning 